\title{
Childhood Teratoma
}

National Cancer Institute

\section{Source}

National Cancer Institute. Childhood Teratoma. NCI Thesaurus. Code C68626.

A mature or immature teratoma occurring in children. 